ORIGINAL ARTICLE

\title{
Wood quality of five species of the Cerrado for energy purposes
}

\section{Qualidade da madeira de cinco espécies do Cerrado para fins energéticos}

Rogério Dias Marques ${ }^{1}$ (ㅇ, Thammi Queuri Gomes da Cunha ${ }^{1}$ (D), Matheus Peres Chagas ${ }^{1}$ (1),

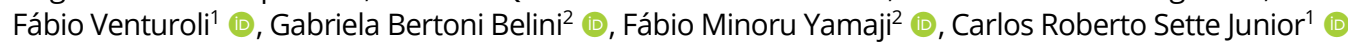

${ }^{1}$ Universidade Federal de Goiás - UFG, Goiânia, GO, Brasil

Universidade Federal de São Carlos - UFSCar, Sorocaba, SP, Brasil.

How to cite: Marques, R. D., Cunha, T. Q. G., Chagas, M. P., Venturoli, F., Belini, G. B., Yamaji, F. M., Sette Junior, C. R. (2020). Wood quality of five species of the Cerrado for energy purposes. Scientia Forestalis, 48(125), e3225. https://doi.org/10.18671/scifor.v48n125.11

\begin{abstract}
The knowledge about the native species of the Cerrado is important for the sustainable socio-economic development of the biome by subsidizing the elaboration of policies to promote forest management. However, studies on wood energy characteristics of Cerrado native species are scarce. Therefore, the objective of this study was to evaluate the wood characteristics from the species Annona coriacea, Buchenavia tomentosa, Byrsonima crassifolia, Byrsonima umbellata and Cordia glabrata in order to determine their potential for energy use. Ten trees of each species were selected from a fragment of the Seasonal Semi-deciduous Forest in the state of Goiás, Brazil. Wood discs were cut to determine the high heating value, proximate analysis, total extractives, insoluble lignin and holocellulose contents, as well as the wood and energetic density, fuel value index and thermal decomposition profile by thermogravimetry in nitrogen atmosphere. The wood of $B$. tomentosa had the best characteristics, with lower ash $(0.26 \%)$ and higher fixed carbon content (16.21\%), high heating value (19.50 MJ kg-1), basic density $\left(581.28 \mathrm{~kg} \mathrm{~m}^{-3}\right)$, energy density $\left(11.33 \mathrm{GJ} \mathrm{m}^{-3}\right.$ ) and fuel value index (4358.74). Therefore, it is indicated for selection in forest management programs of the Cerrado biome for energy applications.
\end{abstract}

Keywords: Bioenergy; Sustainable use; Brazilian savanna; Firewood.

\section{Resumo}

O conhecimento técnico-científico sobre as espécies nativas do Cerrado é importante para o desenvolvimento sócio-econômico sustentável do bioma, subsidiando a elaboração de políticas de fomento ao manejo florestal. No entanto, estudos sobre as características energéticas da madeira de espécies nativas do Cerrado são escassos. Desta forma, o objetivo do trabalho foi avaliar as características da madeira das espécies Annona coriacea, Buchenavia tomentosa, Byrsonima crassifolia, Byrsonima umbellata e Cordia glabrata, visando determinar o seu potencial para o uso energético. De um fragmento de Floresta Estacional Semidecídua no estado de Goiás, Brasil, foram selecionadas dez árvores de cada espécie e cortados discos de madeira para a determinação do poder calorífico superior, análise imediata, teores de extrativos totais, lignina insolúvel e holocelulose; densidades básica e energética, índice de combustibilidade e o perfil de decomposição térmica por termogravimetria em atmosfera de nitrogênio. A madeira da $B$. tomentosa apresentou as melhores características em relação as demais espécies, com menor teores de cinzas $(0,26 \%)$ e maiores teores de carbono fixo $(16,21 \%)$, poder calorífico superior $\left(19,50 \mathrm{MJ} \mathrm{kg}{ }^{-1}\right)$, densidade básica $\left(581,28 \mathrm{~kg} \mathrm{~m}^{-3}\right)$, energética $\left(11,33 \mathrm{GJ} \mathrm{m}^{-3}\right)$ e índice de combustibilidade $(4358,74)$, sendo indicada para a seleção em programas de manejo florestal do bioma Cerrado para aplicações energéticas.

Palavras-chave: Bioenergia; Uso sustentável; Savana brasileira; Lenha.

\section{Financial support: None.}

Conflict of interest: Nothing to declare.

Corresponding author: crsettejr@hotmail.com

Received: 18 December 2018.

Accepted: 10 May 2019.

Editor: Francides Gomes da Silva Júnior.

(c) (i) This is an Open Access article distributed under the terms of the Creative Commons Attribution License, which permits unrestricted use,

c) distribution, and reproduction in any medium, provided the original work is properly cited. 


\section{INTRODUCTION}

Forest biomass is a source of renewable energy, with emphasis on the supply of charcoal, firewood and woodchips for residences, agriculture and industry (Simioni et al., 2017). In Brazil, renewable energy sources account for $43 \%$ of the total demand, and firewood and charcoal contribute $8 \%$ of the energy supply, with an expected increase of $0.4 \%$ in the period from 2017 to 2027 (Empresa de Pesquisa Energética, 2018). Despite the small increase in demand for firewood and charcoal, the share of forest biomass in the Brazilian energy matrix may increase, especially generation of electricity, including distributed generation and self-production, with emphasis on energy efficiency.

Although the use of biomass from planted forests, especially short-rotation species such as those from the Eucalyptus genus has increased in recent years (Caurla et al., 2018), wood from native species in regions such as the Cerrado is used as a raw material for energy generation (Simioni et al., 2017), often in a predatory manner and without a management plan (Vale et al., 2002).

One of the ways to achieve the sustainable use of Cerrado native woods is through selecting species for forest management; this practice may provide information about economic activities in native forests, being a key point for the regulation of the sustainable use of forest resources (Gasson et al., 2018). There are alternatives of use that can serve as incentive to forest management in Central Brazil, which combine the market trends associated with carbon credits and the reduction of emissions from deforestation and forest degradation, and which converge to stimulate the appropriateness of the Brazilian Forest Code, being an option of use for the Legal Reserve in rural properties (Venturoli et al., 2015).

Some scientific studies suggest the use of native vegetation management programs in order to propose economic benefits for forest use, with low impact on the local ecosystem (Verschuyl et al., 2011; Orellana \& Vanclay, 2018). The possibility of exploitation of the native forest through a forest management plan has allowed the sustainable use of wood (Cardoso et al., 2015; Numazawa et al., 2017; Reyes et al., 2018).

The strategy for managing forest resources should be local and not general, since the growth and development of the tree as well as the characteristics of the wood can be different according to the edaphic and climatic conditions, and each country, or even region, must develop strategies independent from biomass production or management programs for more appropriate use of timber resources (Mola-Yudego et al., 2017).

Also, it is necessary to generate information about the species such as dispersion and abundance, dendrometric and growth data, as well as the characteristics of the wood and other ecological information (Padilha \& Marco Júnior, 2018; Granato-Souza et al., 2019). According to Karsten et al. (2014) to select native species for the sustainable use of wood it is recommended to study silvicultural methods, explotaitation intensity, cutting cycles and wood characteristics.

Studies on wood energy characteristics of Cerrado native species are still scarce. However, it is known how important it is to obtain such information, since they can contribute to the sustainable socio-economic development of the biome by subsidizing the elaboration of public policies to promote forest management. In this context, the present study aimed to evaluate the energetic, physical and chemical characteristics of the wood from widely distributed native species in the Cerrado and the influence of the chemical characteristics on the high heating value.

\section{MATERIAL AND METHODS}

Study area and species

Trees of the species Annona coriacea Mart. (Annonaceae), Buchenavia tomentosa Eichler (Combretaceae), Byrsonima crassifolia (L.) Rich. (Malpighiaceae), Byrsonima umbellata A. Juss. (Malpighiaceae) and Cordia glabrata (Mart.) A. DC. (Boraginaceae), popularly known in the 
Brazilian Cerrado as Araticum, Mirindiba, Murici, Muricizinho and Louro-branco, respectively, were selected for this study.

The species were selected because they are abundant and widely distributed in the Cerrado biome and had been cut under an extraction permit issued by the State Department of the Environment of Goiás, being from a fragment of the Seasonal Semi-deciduous Forest, classified as Murundus Field, and located in the rural area of Nova Crixás, Goiás, Brazil. The predominant climate of the region is Aw according to Köppen classification, defined as tropical humid, with a rainy season in the summer and dry in the winter. The mean annual rainfall is $1,500 \mathrm{~mm}$ and the mean temperature varies between $26^{\circ} \mathrm{C}$ and $27^{\circ} \mathrm{C}$.

Selection of trees and preparation of samples

Ten trees of each species were randomly selected. Wood discs were removed from the base $(0 \mathrm{~m}), \mathrm{DBH}(1.30 \mathrm{~m}$ high) and top (minimum diameter $6 \mathrm{~cm})$. The wood disks were fractionated into four wedges, destined for energetic, physical and chemical characterization, in which: (i) two opposing wedges were used to determine the wood basic density (Associação Brasileira de Normas Técnicas, 2003) and (ii) two opposing wedges were crushed and milled for energy and chemical analysis. For this, a composite sample of the three longitudinal positions of the trunk (base, DBH and top) was submitted to mechanical separation in an orbital sieve shaker in order to select the fraction retained in the sieve with 60 mesh, according to TAPPI standards T $264 \mathrm{~cm}-97$ (Technical Association of Pulp and Paper Industry, 1997b) and TAPPI T 257 cm-02 (Technical Association of Pulp and Paper Industry, 2002).

Energetic and chemical characteristics of wood

The following variables were determined for the wood energetic and chemical characterization:

i. proximate analysis (volatile materials, ash and fixed carbon contents) based on ASTM E872-82 and ASTM D1102-84.34 (American Society for Testing Material, 2013a, 2013c);

ii. high heating value (HHV) determined by means of a calorimetric pump according to ASTM D5865-13 (American Society for Testing Material, 2013b);

iii. wood energy density, being the product of HHV and the wood basic density;

iv. insoluble lignin contents, according to TAPPI T 222 om-98 standard (Technical Association of Pulp and Paper Industry, 2011);

v. total extractives content, obtained from the sum of extractives in organic solvent, based on the Tappi T204 cm-97 standard (Technical Association of Pulp and Paper Industry, 1997a) and extractives in hot water, according to Tappi T207 cm-99 standard (Technical Association of Pulp and Paper Industry, 1999);

vi. holocellulose content: obtained by the difference of the total in relation to insoluble lignin contents and total extractives, as suggested by Sette Junior et al. (2014) and Hsing et al. (2016).

vii. Thermal gravimetric analysis - TGA (Perkin Elmer, Pyris 1), according to ASTM D 7582 (American Society for Testing Material, 2015), with analysis range of $50{ }^{\circ} \mathrm{C}$ to $800{ }^{\circ} \mathrm{C}$, heating rate of $20^{\circ} \mathrm{C} \mathrm{min}-1$ and nitrogen atmosphere (purity $>99,9997 \%$ ), flow rate of $20 \mathrm{ml} \mathrm{min}$. . The results were expressed and analyzed by the Pyris software, fully tested on Windows ${ }^{\circledR}$ operating system and Origin Pro 8.0.

viii. Fuel Value Index (FVI), calculated according to the methodology proposed by Musule et al. (2018), without considering humidity percentage in field and in accordance with the following equation:

$\mathrm{FVI}=\frac{\text { HHV }^{*} \text { Wood density }}{\text { Ash content }}$ 


\section{Statistical Analysis}

The statistical analysis was based on a completely randomized experimental design, with five treatments (species) and ten replications (trees). The outliers were checked by the Box-Plot method, the data distribution normality by the Shapiro-Wilk method and variance heterogeneity by the Bartlett and Levene methods. Data were submitted to the analysis of variance and the means were compared by the Tukey test at $5 \%$ of probability. The coefficient of Pearson's correlation was determined to measure the association between the chemical characteristics and the high heating value.

\section{RESULTS AND DISCUSSION}

\section{Wood characteristics}

The analysis of variance indicated a difference in chemical composition among the evaluated species (Table 1). A. coriacea wood presented higher insoluble lignin content compared to the other species, with lower extractive content.

Table 1 - Wood chemical characteristics of species

\begin{tabular}{cccc}
\hline Species & $\begin{array}{c}\text { Insoluble lignin } \\
\text { content (\%) }\end{array}$ & $\begin{array}{c}\text { Holocellulose } \\
\text { content (\%) }\end{array}$ & $\begin{array}{c}\text { Total extractive } \\
\text { content (\%) }\end{array}$ \\
\hline A. coriacea & $30.24 \mathrm{a}$ & $62.33 \mathrm{c}$ & $5.99 \mathrm{~d}$ \\
B. tomentosa & $25.95 \mathrm{c}$ & $59.90 \mathrm{~d}$ & $13.18 \mathrm{a}$ \\
B. crassifolia & $24.51 \mathrm{~d}$ & $65.49 \mathrm{a}$ & $9.03 \mathrm{~b}$ \\
B. umbellata & $26.16 \mathrm{c}$ & $64.51 \mathrm{~b}$ & $8.13 \mathrm{bc}$ \\
C. glabrata & $28.84 \mathrm{~b}$ & $62.43 \mathrm{c}$ & $7.96 \mathrm{c}$ \\
\hline
\end{tabular}

Means followed by the same letter in the column do not differ by the Tukey test at $5 \%$ of probability.

The joint assessment of the chemical constituents of wood is fundamental to indicate the energetic use of wood, since the higher the lignin and extractive contents and the lower the holocellulose contents, the better the wood for energy purposes (Costa et al., 2014). In this sense, even though $A$. coreacea presented a higher insoluble lignin content (30.24\%), better energy performance can be expected for $B$. tomentosa, since a more adequate chemical composition is verified with higher extractive and lignin contents when evaluated together (extractives: $13.18 \%$ + lignin: $25.95 \%=39.13 \%$ ) and lower holocellulose content $(59.90 \%)$ (Table 1).

Other evaluations of the fast-growing pioneer species native of the Cerrado indicated average levels of extractives, holocellulose and insoluble lignin of $6.24,68.62$ and $23.31 \%$ respectively (Costa et al., 2014).

The chemical analysis indicated similarity for the insoluble lignin, holocellulose and extractives contents of the studied native species (Table 1) relative to the levels observed in the literature for species of the Eucalyptus genus, widely used in the forestry sector for energy purposes (Morais et al., 2016; Silva et al., 2017).

$B$. tomentosa wood presented the better energy characteristics than the other species (Table 2), with a lower ash (0.26\%) and higher fixed carbon content (16.21\%), HHV (19.50 MJ kg-1),

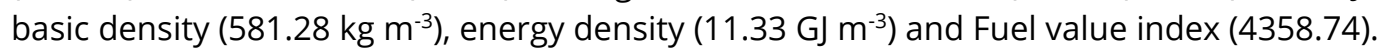

The combustion of biomass produces ash, composed primarily of the inorganic elements naturally present in biomass. These ashes are often disposed of in landfills, which is currently becoming unattractive due to costs and environmental problems (Voshell et al., 2018).

In this study, the ash content varied from 0.26 to $0.62 \%$. The Tukey test showed differences among species. However, these values can be considered low (ash > 1\%) for wood. 
The ashes result from an accumulation of minerals in the plant tissues and the contents vary according to the biomass source (Magdziarz et al., 2018).

A. coriacea e C. glabrata presented the highest levels of volatile contents in the wood (Table 2). Volatile materials are of fundamental importance in the combustion of wood. For example, volatiles mix with the oxygen in the air and promote homogeneous combustion reactions. Thus, higher contents of volatile materials promote a reduction in the ignition temperature of the biomass and greater reactivity of the combustion.

Table 2 - Wood energetic and physical characteristics of species

\begin{tabular}{cccccccc}
\hline Species & $\begin{array}{c}\text { AC } \\
\mathbf{( \% )}\end{array}$ & $\begin{array}{c}\text { VM } \\
\mathbf{( \% )}\end{array}$ & $\begin{array}{c}\text { FC } \\
\mathbf{( \% )}\end{array}$ & $\begin{array}{c}\text { HHV } \\
\left(\mathbf{M} \mathbf{~ k g}^{-\mathbf{1}}\right)\end{array}$ & $\begin{array}{c}\text { WBD } \\
\left(\mathbf{k g ~ m}^{-3} \mathbf{)}\right.\end{array}$ & $\begin{array}{c}\text { WED } \\
\left(\mathbf{G} \mathbf{~ ~ m ^ { - 3 }} \mathbf{)}\right.\end{array}$ & $\begin{array}{c}\text { Fuel Value } \\
\text { Index }\end{array}$ \\
\hline A. coriacea & $0.30 \mathrm{c}$ & $88.17 \mathrm{a}$ & $11.53 \mathrm{c}$ & $18.71 \mathrm{c}$ & $531.67 \mathrm{~b}$ & $9.95 \mathrm{~b}$ & $3315.72 \mathrm{~b}$ \\
B. tomentosa & $0.26 \mathrm{c}$ & $83.53 \mathrm{~b}$ & $16.21 \mathrm{a}$ & $19.50 \mathrm{a}$ & $581.28 \mathrm{a}$ & $11.33 \mathrm{a}$ & $4358.74 \mathrm{a}$ \\
B. crassifolia & $0.48 \mathrm{~b}$ & $83.87 \mathrm{~b}$ & $15.65 \mathrm{a}$ & $19.30 \mathrm{~b}$ & $492.48 \mathrm{~b}$ & $9.51 \mathrm{~b}$ & $1980.34 \mathrm{c}$ \\
B. umbellata & $0.50 \mathrm{~b}$ & $85.15 \mathrm{~b}$ & $14.35 \mathrm{~b}$ & $19.20 \mathrm{~b}$ & $453.27 \mathrm{c}$ & $8.70 \mathrm{c}$ & $1740.65 \mathrm{c}$ \\
C. glabrata & $0.62 \mathrm{a}$ & $87.61 \mathrm{a}$ & $11.77 \mathrm{c}$ & $19.18 \mathrm{~b}$ & $534.43 \mathrm{~b}$ & $10.25 \mathrm{~b}$ & $1653.50 \mathrm{c}$ \\
\hline
\end{tabular}

$\mathrm{AC}=$ ash content; $\mathrm{VM}=$ volatile materials content; $\mathrm{FC}$ : fixed carbon content; $\mathrm{HHV}=$ high heating value; $\mathrm{WBD}=$ wood basic density; WED = wood energy density. Means followed by the same letter in the column do not differ by the Tukey test at $5 \%$ of probability.

The fixed carbon content represents the remaining mass after the release of volatile compounds; excluding ash and moisture content (Carneiro et al., 2013). In this sense, $B$. tomentosa and $B$. crassifolia wood presented higher fixed carbon contents than the others, indicating its suitability for energy purposes.

The chemical composition of biomass, mainly lignin and extractives, exert influence on the HHV due to the fact that they have less oxygen in their composition when compared to the polysaccharides present in holocellulose, which present little complex structures and therefore a greater tendency for thermal degradation (Silva et al., 2014).

The literature indicates that there is usually a highly significant linear correlation between high heating value and lignin and extractive content (Telmo \& Lousada, 2011). However, for the native species of the Cerrado biome evaluated in this study, total extractive content $(r=0.87$; P-value $<0.05$ ) (Figure 1) influenced HHV values more than the lignin content $(r=-0.78$; P-value $<0.05)$. Medeiros Neto et al. (2014) when evaluating the relationships between wood characteristics of two Caatinga species, in Brazil, also observed a negative relationship between HHV and lignin content.

The total extractives contributed significantly to the increase of the fixed carbon content in the wood; a linear and positive correlation was identified ( $r=0.78$; P-value $<0.05)$ (Figure 1). In the same way, the fixed carbon content is directly related to the high heating value observed in the species studied; the increase of fixed carbon contents are associated with high HHV values $(r=0.79$; P-value $<0.05)$ (Figure 1$)$. This relationship is commonly reported in the literature (Santos et al., 2016; Sette Junior et al., 2017).

Comparatively, seven-year-old wood from the hybrid $E$. urophylla $\times$ E. grandis planted in the Cerrado region, Brazil, studied by Sette Junior et al. (2018) presented a high heating value of $19.48 \mathrm{MJ} \mathrm{kg}^{-1}$, similar to the native species evaluated. In a study carried out in the Caatinga biome, Brazil, the HHV of forest species averaged $19.43 \mathrm{MJ} \mathrm{kg}^{-1}$ (Brand, 2017) and in the Cerrado area with gallery forest the species Sclerolobium paniculatum and Plathymenia reticulata presented 22.69 and $22.02 \mathrm{MJ} \mathrm{kg}^{-1}$, respectively (Machado Neto et al., 2015). 

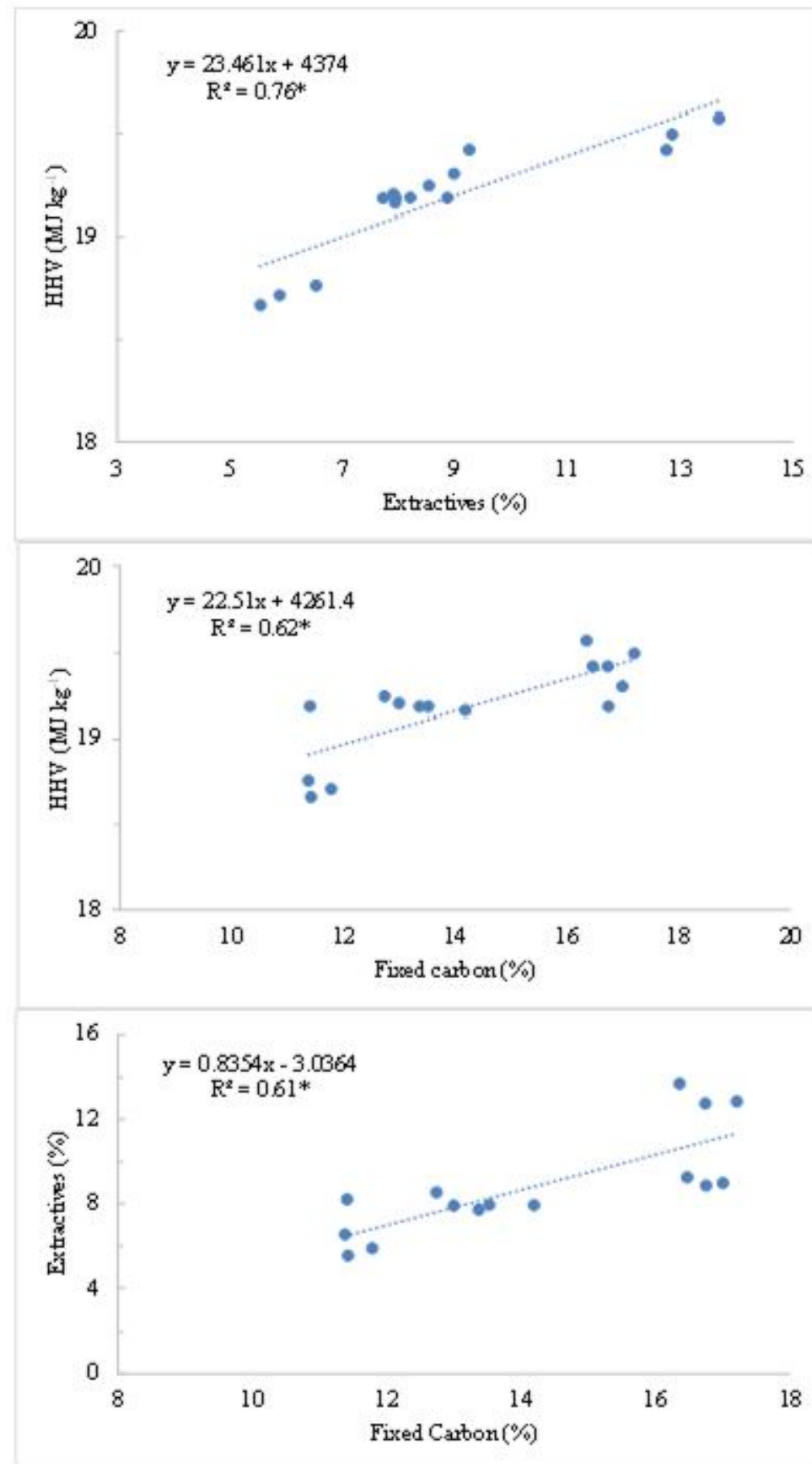

Figure 1 - Relationship between high heating value (HHV), total extractives and fixed carbon contents.

B. tomentosa presented up to $23.0 \%$ higher wood and energy densities in relation to the other species (Table 2). The mean wood density of native species of this study $\left(518.63 \mathrm{~kg} \mathrm{~m}^{-3}\right)$ is similar to the species of the Byrsonima genus $\left(540 \mathrm{~kg} \mathrm{~m}^{-3}\right.$ ) (Vale et al., 2002; Costa et al., 2014; Machado Neto et al., 2015).

Knowledge about wood density supports understanding the dynamics of forest growth and subsidizes the discussion on the wood use of native species (Padilha \& Marco Júnior, 2018; Pretzsch et al., 2018). This variable is the best feature to distinguish the most appropriate use of wood among a set of variables (Padilha \& Marco Júnior, 2018) and is related to other characteristics of the biomass, influencing the energy density of the biofuel (Sette Junior et al., 2018). 
The fuel value index (FVI) estimates species combustibility and the ability to produce hot flame and is the quality criterion most frequently used in ranking the preferred fuelwood species (Deka et al., 2007; Cardoso et al., 2015). B. tomentosa presented higher combustibility values than the others species. This result is related to there higher values of $\mathrm{HHV}$ and wood density and lower values of ash contents (Table 2). Bhatt et al. (2010) when evaluating fuelwood characteristics of some firewood trees of eastern Himalaya, India, found FVI values ranging from 306.9 to 1178.6; lower than those observed in this study. This difference is associated to the higher ash contents in the wood of the species studied by the authors, being inversely proportional to the FVI.

Knowledge of the characteristics of wood of native species is a tool to subsidize forest management, offering practical solutions for the appropriate use of high quality bioenergy resources. For native Cerrado species, few scientific studies were carried out using the wood chemical composition, physical and energetic properties as criteria to evaluate the biofuel potential of timber species (Vale et al., 2002; Costa et al., 2014). Thus, the results presented in this study are important to supply part of the lack of information about the native species of the Cerrado.

\section{Thermogravimetry}

A thermogravimetric analysis was performed and its derivative calculated (Figure 2 and Table 3) in order to know the thermogravimetric profile (TGA) of the biomass and the chemical components of the different species.

It was possible to observe similar thermal degradation behavior for all species, with the presence of four stages of mass loss: event I (mass loss by elimination of free and hygroscopic water), event II (degradation of chemical structure of the biomass, with complete degradation of hemicellulose and the beginning of cellulose and lignin degradation), event III (degradation of thermally resistant substances such as lignin and complete degradation of cellulose), and event IV (degradation of all chemical constituents, leaving only the inorganic chemical elements). The yields indicate the maximum biomass mass loss during thermodegradation occurred at $394{ }^{\circ} \mathrm{C}$ for B. tomentosa, $402{ }^{\circ} \mathrm{C}$ for B. umbellata, $396{ }^{\circ} \mathrm{C}$ for B. crassifolia and A. coreacea, and $403^{\circ} \mathrm{C}$ for C. Glabrata (Figure 2).

In addition, a common phase between 150 and $250^{\circ} \mathrm{C}$ (end of event I and intermediate phase of event II) was observed for all species, with stabilization of mass loss. It is possible to observe a final stable phase of mass loss as a function of the applied temperature (around $700{ }^{\circ} \mathrm{C}$ ), common to all species (Figure 2). It represents the residual solid mass after thermal degradation carried out in an atmosphere of nitrogen, consisting of fixed carbon and ashes and which make up the total of 17 to $21 \%$ of the initial mass.

Table 3 presents the initial and final degradation temperature values, as well as the mass loss of samples per event. The initial temperature (Ti) was determined by using function "onset" and final temperature (Tf) as done by "endset" function of Pyris1 software (TGA).

The mass loss for event I varied around $10 \%$ for all species. For $A$. coreacea, the greatest mass loss was observed between the temperatures of 153 and $447^{\circ} \mathrm{C}$, with $64 \%$ of its initial mass degraded, and from this last temperature onward there was a small variation in mass (from 447 to $698^{\circ} \mathrm{C}$ ); $7 \%$ of mass loss which occurred in event IV. For the other species, the beginning of the phase of greatest mass loss (stage II) occurred at higher temperatures; $167^{\circ} \mathrm{C}$ for C. glabrata, $168^{\circ} \mathrm{C}$ for B. umbellata, $170^{\circ} \mathrm{C}$ for B. crassifolia and $175^{\circ} \mathrm{C}$ for B. tomentosa with temperatures ranging from 452 to $467^{\circ} \mathrm{C}$ (stage III), with small variations of mass between 6 and $9 \%$ being similarly observed from these temperatures onward (stage IV). 



Figure 2 - Thermal gravimetric curves (TG) and their derivative (DTG) of A. coriacea (A), B. tomentosa (B), B. crassifolia (C), B. umbellata (D) and C. glabrata (E).

The results obtained in the TGA confirm that the chemical components (hemicellulose, cellulose and lignin) degrade at different temperature ranges, as indicated in the literature; hemicellulose is more sensitive to the effects of temperature and is the polymer that decomposes first, between 190 and $360^{\circ} \mathrm{C}$. The degradation of cellulose occurs between $300-400^{\circ} \mathrm{C}$, and finally lignin, which decomposes more slowly over a wide temperature range, between 150 and $500^{\circ} \mathrm{C}$ (Shen et al., 2010).

The behavior observed in this study for the five species with the characterization of the four events is the one commonly pointed out in the literature for wood (Van de Velden et al., 2010; Carneiro et al., 2013; Protásio et al., 2015). However, data on the thermogravimetric behavior of the native wood of the Cerrado are scarce. Mass loss stabilization (Figure 2) is interpreted as a region of thermal stability of the wood and its chemical constituents (Le Floch et al., 2015).

Studies on the thermodegradation of Eucalyptus spp. also presented stability range varying between 100 and $200{ }^{\circ} \mathrm{C}$ (Pereira et al., 2013). In the TGA analysis to evaluate the thermal degradation of eucalyptus clones in the same atmosphere of nitrogen, Santos et al. (2012) and Pereira et al. (2013) obtained residual mass ranging from 15 to 20\%. 
Table 3 - Initial temperature $(\mathrm{Ti})$, final temperature $(\mathrm{Tf})$ and percentage of mass loss of each event by species

\begin{tabular}{|c|c|c|c|c|}
\hline Species & Event & $\mathrm{Ti}\left({ }^{\circ} \mathrm{C}\right)$ & $\operatorname{Tf}\left({ }^{\circ} \mathrm{C}\right)$ & Mass loss (\%) \\
\hline \multirow[t]{4}{*}{ A. coriacea } & I & 31 & 153 & 10 \\
\hline & II & 153 & 379 & 33 \\
\hline & III & 379 & 447 & 31 \\
\hline & IV & 447 & 698 & 7 \\
\hline \multirow[t]{4}{*}{ B. tomentosa } & I & 39 & 175 & 9 \\
\hline & II & 175 & 373 & 28 \\
\hline & III & 373 & 452 & 33 \\
\hline & IV & 452 & 711 & 9 \\
\hline \multirow[t]{4}{*}{ B. crassifolia } & I & 28 & 170 & 10 \\
\hline & II & 170 & 376 & 28 \\
\hline & III & 376 & 456 & 33 \\
\hline & IV & 456 & 703 & 8 \\
\hline \multirow[t]{4}{*}{ B. umbellata } & I & 29 & 168 & 9 \\
\hline & II & 168 & 374 & 25 \\
\hline & III & 374 & 460 & 37 \\
\hline & IV & 460 & 710 & 8 \\
\hline \multirow[t]{4}{*}{ C. glabrata } & I & 29 & 167 & 10 \\
\hline & II & 167 & 371 & 26 \\
\hline & III & 371 & 467 & 41 \\
\hline & IV & 467 & 709 & 6 \\
\hline
\end{tabular}

Thermogravimetry can subsidize the control of the carbonization process in furnaces by associating the internal temperature to the degradation phases of the wood components. By the TGA analysis it is possible to set periods that the furnace must remain in each temperature range, which can contribute to an increase in the charcoal yield (Pereira et al., 2013).

\section{CONCLUSION}

The $B$. tomentosa wood presented the best characteristics than the other species, with a lower ash (0.26\%) and higher fixed carbon content (16.21\%), high heating value (19.50 $\left.\mathrm{MJ} \mathrm{kg}^{-1}\right)$, basic density $\left(581.28 \mathrm{~kg} \mathrm{~m}^{-3}\right)$, energy density $\left(11.33 \mathrm{G} \mathrm{J} \mathrm{m}^{-3}\right.$ ) and fuel value index (4358.74). Therefore, it is indicated for selection in forest management programs of the Cerrado biome for energy applications.

For the studied wood species, total extractive and fixed carbon contents influenced positively the HHV values. The TGA is suitable to understand the biomass behavior during thermal degradation.

\section{REFERENCES}

American Society for Testing Material - ASTM. (2013a). ASTM D 1102-84: standard test method for ash in wood. West Conshohocken: ASTM.

American Society for Testing Material - ASTM. (2013b). ASTM D 5865-13: standard test method for gross calorific value of coal and coke. West Conshohocken: ASTM.

American Society for Testing Material - ASTM. (2013c). ASTM E 872-82: standard test method for volatile matter in the analysis of particulate wood fuels. Phyladelphia: ASTM.

American Society for Testing Material - ASTM. (2015). ASTM D 7582: standard test methods for proximate analysis of coal and coke by macro thermogravimetric analysis. Phyladelphia: ASTM. 
Associação Brasileira de Normas Técnicas - ABNT. (2003). NBR 11941: madeira: determinação da densidade básica. Rio de Janeiro: ABNT.

Bhatt, B. P., Sarangi, S. K., \& De, L. C. (2010). Fuelwood characteristics of some firewood trees and shrubs of eastern Himalaya, India. Energy Sources. Part A, Recovery, Utilization, and Environmental Effects, 32(5), 469-474. http://dx.doi.org/10.1080/15567030802612408.

Brand, M. A. (2017). Potencial de uso da biomassa florestal da caatinga, sob manejo sustentável, para geração de energia. Ciência Florestal, 27(1), 117-127. http://dx.doi.org/10.5902/1980509826452.

Cardoso, M. B., Ladio, A. H., Dutrus, S. M., \& Lozada, M. (2015). Preference and calorific value of fuelwood species in rural populations in northwestern Patagonia. Biomass and Bioenergy, 81, 514520. http://dx.doi.org/10.1016/j.biombioe.2015.08.003.

Carneiro, A. C. O., Santos, R. C., Castro, R. V. O., Castro, A. F. N., Pimenta, A. S., Pinto, E. M., \& Alves, I. C. N. (2013). Estudo da decomposição térmica da madeira de oito espécies da região do Seridó, Rio Grande do Norte. Revista Árvore, 37(6), 1153-1163. http://dx.doi.org/10.1590/S010067622013000600017.

Caurla, S., Bertrand, V., Delacote, P., \& Le Cadre, E. (2018). Heat or power: how to increase the use of energy wood at the lowest cost? Energy Economics, 75, 85-103. http://dx.doi.org/10.1016/j.eneco.2018.08.011.

Costa, T. G., Bianchi, M. L., Protásio, T. P., Trugilho, P. F., \& Pereira, A. J. (2014). Wood quality of five species from Cerrado for production of charcoal. Cerne, 20(1), 37-45. http://dx.doi.org/10.1590/S0104-77602014000100005.

Deka, D., Saikia, P., \& Konwer, D. (2007). Ranking of fuelwood species by fuel value index. Energy Sources, 29(16), 1499-1506. http://dx.doi.org/10.1080/15567030600820476.

Empresa de Pesquisa Energética - EPE. (2018). Plano decenal de expansão de energia 2027. Rio de Janeiro: EPE.

Gasson, P., Pareyn, F., Sampaio, E. V. S. B., Lee, M., Baracat, A., Araújo, E. L., \& Cutler, D. (2018). Impact of management regime and frequency on the survival and productivity of four native tree species used for fuelwood and charcoal in the caatinga of northeast Brazil. Biomass and Bioenergy, 116, 1825. http://dx.doi.org/10.1016/j.biombioe.2018.05.010.

Granato-Souza, D., Barbosa, A. C. M. C., \& ChaveS, H. F. (2019). Drivers of growth variability of Hymenaea stigonocarpa, a widely distributed tree species in the Brazilian Cerrado. Dendrochronologia, 53, 7381. http://dx.doi.org/10.1016/j.dendro.2018.12.001.

Hsing, T. Y., Paula, N. F., \& Paula, R. C. (2016). Características dendrométricas, químicas e densidade básica da madeira de híbridos de Eucalyptus grandis x Eucalyptus urophylla. Ciência Florestal, 26(1), 273-283. http://dx.doi.org/10.5902/1980509821119.

Karsten, R. J., Meilby, H., \& Larsen, J. B. (2014). Regeneration and management of lesser known timber species in the Peruvian Amazon following disturbance by logging. Forest Ecology and Management, 327, 76-85. http://dx.doi.org/10.1016/j.foreco.2014.04.035.

Le Floch, A., Jourdes, M., \& Teissedre, P. L. (2015). Polysaccharides and lignin from oak wood used in cooperage: composition, interest, assays: a review. Carbohydrate Research, 417, 94-102. PMid:26454166. http://dx.doi.org/10.1016/j.carres.2015.07.003.

Machado Neto, A. P., Brandão, C. F. L. S., Duarte, B., Almir, J., Marangon, L. C., \& Feliciano, A. L. P. (2015). Densidade e poder calorífico como base para prevenção de incêndios florestais sob linhas de transmissão. Nativa, 3(1), 10-15. http://dx.doi.org/10.14583/2318-7670.v03n01a02.

Magdziarz, A., Gajek, M., Nowak-Wozny, D., \& Wilk, M. (2018). Mineral phase transformation of biomass ashes: experimental and thermochemical calculations. Renewable Energy, 128, 446-459. http://dx.doi.org/10.1016/j.renene.2017.05.057.

Medeiros Neto, P. N., Oliveira, E., \& Paes, J. B. (2014). Relações entre as características da madeira e do carvão vegetal de duas espécies da Caatinga. Floresta e Ambiente, 21(4), 484-493. http://dx.doi.org/10.1590/2179-8087.051313.

Mola-Yudego, B., Arevalo, J., Díaz-Yáñez, O., Dimitriou, I., Haapala, A., Ferraz Filho, A. C,, Selkimäki, M., \& Valbuena, R. (2017). Wood biomass potentials for energy in northern Europe: forest or plantations? Biomass and Bioenergy, 106, 95-103. http://dx.doi.org/10.1016/j.biombioe.2017.08.021.

Morais, A. P. S., Sansígolo, C. A., \& Oliveira Neto, M. (2016). Effects of autohydrolysis of Eucalyptus urograndis and Eucalyptus grandis on influence of chemical components and crystallinity index. Bioresource Technology, 214, 623-628. PMid:27187566. http://dx.doi.org/10.1016/j.biortech.2016.04.124. 
Musule, R., Acuña, E., Romero-Hermoso Osorio, L. S., Domínguez, Z., Bárcenas-Pazos, G. M., PinedaLópez, M. R., Teixeira Mendonça, R., González, M. E., \& Sánchez-Velásquez, L. R. (2018). Growing up at different altitudes: changes in energy content of the Abies religiosa wood. BioEnergy Research, 11(1), 209-218. http://dx.doi.org/10.1007/s12155-017-9889-5.

Numazawa, C. T. D., Numazawa, S., Pacca, S., \& John, V. M. (2017). Logging residues and $\mathrm{CO}_{2}$ of Brazilian Amazon timber: two case studies of forest harvesting. Resources, Conservation and Recycling, 122, 280-285. http://dx.doi.org/10.1016/j.resconrec.2017.02.016.

Orellana, E., \& Vanclay, J. K. (2018). Could native Araucaria forests be managed for timber production on small farms in southern Brazil? Forest Ecology and Management, 430, 1-9. http://dx.doi.org/10.1016/j.foreco.2018.07.057.

Padilha, D. L., \& Marco Júnior, P. (2018). A gap in the woods: wood density knowledge as impediment to develop sustainable use in Atlantic Forest. Forest Ecology and Management, 424, 448-457. http://dx.doi.org/10.1016/j.foreco.2018.05.012.

Pereira, B. L. C., Carneiro, A. C. O., Carvalho, A. M. M. L., Colodette, J. L., Oliveira, A. C., \& Fontes, M. P. F. (2013). Influence of chemical composition of eucalyptus wood on gravimetric yield and charcoal properties. BioResources, 8(3), 4574-4592. http://dx.doi.org/10.15376/biores.8.3.4574-4592.

Pretzsch, H., Biber, P., Schütze, G., Kemmerer, J., \& Uhl, E. (2018). Wood density reduced while wood volume growth accelerated in Central European forests since 1870. Forest Ecology and Management, 429, 589-616. http://dx.doi.org/10.1016/j.foreco.2018.07.045.

Protásio, T. P., Mendes, R. F., Scatolino, M. V., Mendes, L. M., Trugilho, P. F., \& Melo, I. C. N. (2015). Estabilidade térmica de painéis aglomerados de bagaço de cana-de-açúcar e madeira de Pinus spp. Scientia Forestalis, 43, 683-691.

Reyes, R., Nelson, H., \& Zerriffi, H. (2018). Firewood: cause or consequence? Underlyingdrivers of firewood production in the South of Chile. Energy for Sustainable Development, 42, 97-108.

Santos, D. R., Sette Junior, C. R., Silva, M. F., Yamaji, F. M., \& Almeida, R. A. (2016). Potencial de espécies de Bambu como fonte energética. Scientia Forestalis, 44(111), 1-10. http://dx.doi.org/10.18671/scifor.v44n111.21.

Santos, R. C., Carneiro, A. C. O., Trugilho, P. F., Mendes, L. M., \& Carvalho, A. M. M. L. (2012). Análise termogravimétrica em clones de eucalipto como subsídio para a produção de carvão vegetal. Cerne, 18(1), 143-151. http://dx.doi.org/10.1590/S0104-77602012000100017.

Sette Junior, C. R., Hansted, A. L. S., Novaes, E., Lima, P. A. F., Rodrigues, A. C., Santos, D. R. S., \& Yamaji, F. M. (2018). Energy enhancement of the eucalyptus bark by briquette production. Industrial Crops and Products, 122, 209-213. http://dx.doi.org/10.1016/j.indcrop.2018.05.057.

Sette Junior, C. R., Lima, P. A. F. L., Lopes, D. M. M., Barbosa, P. V. G., Coneglian, A., \& Almeida, R. A. (2017). Characterization of biomass, charcoal and briquette of Phyllostachys aurea Carr. ex A. \& C. Rivière. Scientia Forestalis, 45(116), 619-628. http://dx.doi.org/10.18671/scifor.v45n116.03.

Sette Junior, C. R., Tomazello Filho, M., Silva Junior, F. G., \& Laclau, J. P. (2014). Alterações nas características químicas da madeira com a substituição do $\mathrm{K}$ por Na em plantações de eucalipto. Revista Árvore, 38(3), 569-578. http://dx.doi.org/10.1590/S0100-67622014000300020.

Shen, R., Gu, S., \& Bridgwater, A. V. (2010). The thermal performance of the polysaccharides extracted from hardwood: cellulose and hemicelluloses. Carbohydrate Polymers, 82(1), 39-45. http://dx.doi.org/10.1016/j.carbpol.2010.04.018.

Silva, C. M. S., Vital, B. R., Carneiro, A. C. O., Costa, E. V. S., Magalhães, M. A., \& Trugilho, P. F. (2017). Structural and compositional changes in eucalyptus wood chips subjected to dry torrefaction. Industrial Crops and Products, 109, 598-602. http://dx.doi.org/10.1016/j.indcrop.2017.09.010.

Silva, D. A., Almeida, V. C., Viana, L. C., Klock, U., \& Muniz, G. I. B. (2014). Avaliação das propriedades energéticas de resíduos de madeiras tropicais com uso da espectroscopia NIR. Floresta e Ambiente, 21(4), 561-568. http://dx.doi.org/10.1590/2179-8087.043414.

Simioni, F. J., Moreira, J. M. M. A. P., Fachinello, A. L., Buschinelli, C. C. A., \& Matsuura, M. I. S. F. (2017). Evolução e concentração da produção de lenha e carvão vegetal da silvicultura no Brasil. Ciência Florestal, 27(2), 731-742. http://dx.doi.org/10.5902/1980509827758.

Technical Association of Pulp and Paper Industry - TAPPI. (1997a). T204 cm-97: solvent extractives of wood and pulp: TAPPI test methods. Atlanta: TAPPI.

Technical Association of Pulp and Paper Industry - TAPPI. (1997b). T264 cm-97: preparation of wood for chemical analysis: TAPPI test methods. Atlanta: TAPPI. 
Technical Association of Pulp and Paper Industry - TAPPI. (1999). T207cm-99: water solubility of wood and pulp: TAPPI test methods. Atlanta: TAPPI.

Technical Association of Pulp and Paper Industry - TAPPI. (2002). T257 cm-02: sampling and preparing wood for analysis: TAPPI test methods. Atlanta: TAPPI.

Technical Association of Pulp and Paper Industry - TAPPI. (2011). T222 om-02: lignin in wood and pulp: TAPPI test methods. Atlanta: TAPPI.

Telmo, C., \& Lousada, J. L. (2011). The explained variation by lignin and extractive contentes on higher heating value of wood. Biomass and Bioenergy, 35(5), 1663-1667. http://dx.doi.org/10.1016/j.biombioe.2010.12.038.

Vale, A. T., Brasil, M. A. M., \& Leão, A. L. (2002). Quantificação e caracterização energética da madeira e casca de espécies do cerrado. Ciência Florestal, 12(1), 71-80. http://dx.doi.org/10.5902/198050981702.

Van de Velden, M., Baeyens, J., Brems, A., Janssens, B., \& Dewil, R. (2010). Fundamentals, kinetics and endothermicity of the biomass pyrolysis reaction. Renewable Energy, 35(1), 232-242. http://dx.doi.org/10.1016/j.renene.2009.04.019.

Venturoli, F., Carvalho, F. A., Silva Neto, C. M., Moraes, D. C., Martins, T. O., \& Souza, D. M. (2015). Manejo Florestal no bioma Cerrado: uma opção para conservar e lucrar. Scientia Forestalis, 43(107), 617-626.

Verschuyl, J., Riffell, S., Miller, D., \& Wigley, T. B. (2011). Biodiversity response to intensive biomass production from forest thinning in North American forests: a meta-analysis. Forest Ecology and Management, 261(2), 221-232. http://dx.doi.org/10.1016/j.foreco.2010.10.010.

Voshell, S., Makela, M., \& Dahl, O. (2018). A review of biomass ash properties towards treatment and recycling. Renewable \& Sustainable Energy Reviews, 96, 479-486. http://dx.doi.org/10.1016/j.rser.2018.07.025.

Authors' contributions: RDM, TQGC and GBB: investigation, data curation, formal analysis, methodology; MPC, FV and FMY: conceptualization, writing, validation; CRSJ: conceptualization, supervision, project administration, writing. 